\title{
Upaya Meningkatkan Aktivitas dan Hasil Belajar Peserta Didik Melalui Pemberian Reward dan Punishment pada Mata Pelajaran Matematika
}

\author{
Erni Suharti \\ SMA Negeri 8 Padang, Padang, Sumatera Barat \\ ernisuharti70@gmail.com
}

\begin{abstract}
During the learning process students tend to be passive and learning is centered on the teacher, so activity and learning outcomes are low. One of the efforts that can be done is the provision of rewards and punishments during the learning process. The purpose of this study was to increase student activity and learning outcomes through the provision of rewards and punishments. This type of research is classroom action research using a qualitative approach, which is supported by a quantitative approach. This research consists of four stages, namely planning, action, observation, and reflection. This study involved 33 students of class XI MIPA 3 SMAN 8 Padang. Research data obtained through observation sheets, quizzes, learning outcomes tests, and field notes. The data analysis technique used is descriptive analysis. Based on research data in first and second cycles, it shows that the activities and learning outcomes of students have increased. This is indicated by an increase in learning outcomes from $40 \%$ in the first cycle to $67 \%$ in the second cycle. So, it can be concluded that learning by giving rewards and punishments could increase students' activities and learning outcomes.
\end{abstract}

Keywords :Reward and punishment, Activities of learner, Learning outcomes, Mathematics course

This is an open access article distributed under the Creative Commons 4.0 Attribution License, which permits unrestricted use, distribution, and eproduction in any medium, provided the original work is properly cited. $\odot 2021$ by author.

\section{PENDAHULUAN}

Motivasi belajar peserta didik di SMAN 8 Padang belum optimal. Hal ini dapat dilihat dari rendahnya kesadaran yang dimiliki peserta didik untuk berprestasi lebih tinggi. Motivasi belajar yang berasal dari luar juga perlu diperhatikan dan ditindaklanjuti. Oleh karena itu, salah satu tugas guru adalah bagaimana menjadikan motivasi bela jar dari luar sehingga secara tidak langsung moti vasi belajar dari dalam diri peserta didik akan ter bentuk.

Guru harus memiliki suatu strategi agar mampu menumbuhkan motivasi belajar peserta didik secara maksimal. Beberapa kebutuhan yang dimiliki peserta didik diantaranya kebutuhan in telektual (berprestasi), kebutuhan sosial (afiliasi), kebutuhan organisasional (fisik), dan kebutuhan keindahan (Rifa'i, 2012). Kebutuhan intelektual (berprestasi) dapat dicapai dengan pemberian re ward dan punishment dalam pembelajaran. Re ward dapat diberikan ketika peserta didik mela kukan sesuatu yang baik dan tercapainya sebuah target (Shoimin, 2014).

Pada berbagai penelitian menemukan bah wa motivasi merupakan hal yang sangat penting dalam pembelajaran (Ilmiyah dan Sumbawati 2019; Nurmala dkk, 2014). Peserta didik yang termotivasi akan memperoleh hasil belajar yang baik (Lestari, 2017; Murni dkk, 2020). Untuk itu, guru harus selalu meningkatkan motivasi belajar peserta didik (Juita dan Yusmaridi, 2019).

Pemberian reward merupakan suatu upaya yang dilakukan guru guna membangkitkan moti vasi belajar peserta didik (Sardiman, 2011; Hama lik, 2013; Sujiantari, 2016). Lebih lanjut, Slameto (2010) menjelaskan bahwa dengan adanya re ward mendorong peserta didik untuk melakukan berbagai aktivitas berikutnya dalam rangka men capai tujuan pembelajaran. Kesimpulannya bah wa pemberian reward adalah suatu cara yang da pat dilakukan guru untuk menumbuhkan, mem pertahankan, dan menaikkan motivasi belajar pe serta didik agar tercapainya tujuan pembelajaran. Reward yang dimaksud bisa berupa pemberian penghargaan, ganjaran, atau imbalan.

Berdasarkan hasil observasi terhadap pem belajaran pada beberapa kelas dan wawancara de ngan beberapa orang guru matematika di SMA 8 Padang, diperoleh informasi bahwa guru sudah melakukan pemberian reward dan punishment dalam pembelajaran, dan pemberian reward dan punishment tersebut belum dilaksanakan oleh gu ru secara maksimal. Oleh karena itu, diperlukan berbagai upaya untuk mencari solusi untuk perma 
salahan dalam pembelajaran matematika di kelas XI MIPA 3 SMAN 8 Padang.

Salah satu alternatif yang dapat dilakukan adalah melakukan pemberian reward dan $p u$ nishment dalam pembelajaran matematika. Tuju an pemberian ini adalah untuk membuat siswa aktif, menumbuhkan minat, dan meningkatkan kreativitas belajar peserta didik supaya hasil belajar maksimal. Berdasarkan masalah yang telah dipaparkan maka penelitian dengan tindak an pemberian reward dan punishment dilakukan pada Mata Pelajaran Matematika dalam rangka meningkatkan aktivitas dan hasil belajar peserta didik.

\section{METODE PENELITIAN}

Jenis penelitian ini adalah Penelitian Tin dakan Kelas (PTK) dengan dua siklus. Subjeknya adalah 33 peserta didik kelas XI MIPA 3 SMAN 8 Padang pada semester ganjil tahun pelajaran 2019/2020. Tahapan dalam penelitian ini meli puti (1) perencanaan, (2) pelaksanaan, (3) penga matan/ observasi, dan (4) refleksi.

Pada tahap perencanaan, ditetapkan jadwal penelitian, mempersiapkan perangkat pembela jaran, perangkat evaluasi, dan lembar observasi. Langkah selanjutnya adalah pelaksanaan rencana yang telah disusun ke dalam bentuk tindakan. Pada tahap pengamatan, observer akan menga mati aktivitas peserta didik dalam kegiatan pem belajaran kemudian mengisi lembar observasi yang telah disediakan berdasarkan fakta yang terjadi. Kemudian dianalisis data hasil observasi dan menganalisisnya untuk melihat tingkat keber hasilan tindakan dalam mencapai tujuan. Kesim pulan yang diperoleh dari tahap refleksi menjadi bahan pertimbangan untuk menentukan langkah selanjutnya.

Pembelajaran dikatakan berhasil jika $60 \%$ peserta didik memperoleh nilai ketuntasan de ngan KKM 80, yaitu ketentuan yang ditetapkan untuk tahun ajaran 2019/2020. Namun, jika be lum memenuhi maka penelitian diteruskan ke siklus II dengan memperbaiki atau memodiikasi tindakan yang dilaksanakan. Untuk aktivitas peserta didik dikatakan berhasil jika rata-rata persentase tiap indikator telah mencapai 50\% maka aktivitas peserta didik dianggap meningkat dan siklus dihentikan. Peserta didik telah memenuhi setiap indikator aktivitas positif untuk setiap pertemuan.

Data dikumpulkan melalui tes dan non tes. Data tes diambil dari kuis dan ulangan harian di akhir siklus. Data non tes diperoleh dari observasi dan catatan lapangan. Tujuan diberikan tes ada lah untuk melihat seberapa jauh pemahaman pe serta didik terhadap materi yang bermuara pada hasil belajar. Selanjutnya, aktivitas guru dan pe serta didik selama proses pembelajaran dapat dilihat dari hasil observasi dan catatan lapangan yang sudah diisi oleh observer.

Teknik analisis data yang digunakan untuk aktivitas dan hasil belajar matematika peserta didik menggunakan analisis persen, yaitu rumus yang dikemukakan Depdiknas (2008). Hasil analisis persen tersebut kemudian dideskripsikan sesuai dengan tujuan penelitian. Disamping itu juga digunakan statistik rata-rata.

\section{HASIL DAN PEMBAHASAN}

Penelitian ini dilakukan dalam dua siklus, yaitu sikus I dan siklus II.

\section{Hasil Penelitian pada Siklus I}

Siklus I terdiri dari empat kali pertemuan dengan materi yang berbeda untuk setiap perte muannya. Aktivitas guru dan peserta didik dia mati dan didokumentasikan oleh observer selama pembelajaran berlangsung. Aktivitas guru yang diamati terdiri dari (1) kegiatan pendahuluan, (2) kegiatan inti, dan (3) kegiatan penutup.

Kegiatan pendahuluan mencakup kegiatan membuka pelajaran dan mencek kesiapan belajar peserta didik, mengkondisikan kelas dan peserta didik, pemberian motivasi dan apersepsi kepada peserta didik, menyampaikan tujuan pembela jaran yang berhubungan dengan masalah nyata, materi yang akan dibahas dikaitkan dengan ma teri sebelumnya, meninjau kembali beberapa ma teri yang belum dikuasai peserta didik, dan meng atur peserta didik dalam kelompoknya/bekerja dengan teman sebangku. Kegiatan inti merupa kan pelaksanaan tindakan mencakup mengajukan masalah kontekstual, mengajukan pertanyaan ke pada peserta didik, merespon jawaban peserta didik dengan meminta alasan/pendapat, meminta peserta didik untuk berkonfrontasi dengan teman nya, memberikan bimbingan kepada peserta di dik, serta pemberian motivasi dan reward. Selan jutnya kegiatan penutup mencakup peserta didik membuat kesimpulan dan guru memberikan latihan.

Aktivitas peserta didik yang diamati terdiri dari sebelas amatan. Dengan menggunakan lem baran observasi, semua aktivitas dicatat oleh observer. Aktivitas tersebut adalah 1) Peserta di dik bertanya, 2) Peserta didik menanggapi, 3) Peserta didik yang serius, 4) Peserta didik hadir, 
5) Peserta didik yang mengerjakan latihan, 6) Peserta didik mengumpulkan PR, 7) Peserta di dik yang melamun, 8) Peserta didik yang men catat, 9) Peserta didik yang memperhatikan pen jelasan guru, 10) Peserta didik yang mendapat reward, 11) Peserta didik yang mendapat reward lebih dari satu kali, dan 12) Peserta didik yang terlambat.

\section{a. Deskripsi Aktivitas Guru pada Siklus I}

Pada pertemuan pertama guru melakukan apersepsi berupa menginformasikan tujuan pem belajaran, memotivasi peserta didik supaya terli bat aktif dalam pemecahan masalah realistik yang ada pada LKS dan menjelaskan metode pembela jaran dengan memberikan contoh nyata dari benda-benda yang berhubungan dengan topik yang diberikan. Benda-benda yang ditunjukkan dapat mereka jawab dengan bahasanya sendiri, karena masih pertanyaan yang sederhana sekali. Selanjutnya guru mengkondisikan peserta didik untuk berkelompok.

Pada kegiatan inti, guru meminta peserta didik untuk membaca, mencermati dan menyele saikan masalah yang ada pada LKS yang tersedia. Pada pertemuan I peserta didik belum bisa men jawab pertanyaan mengenai menentukan persa maan sinus. Mereka mengalami kesulitan untuk menyusun kata-katanya. Tindakan yang guru la kukan adalah membimbing peserta didik secara individu dan kelompok. Guru memberikan perta nyaan dengan menunjukkan masalah yang ada pada LKS agar peserta didik dapat menemukan jawaban yang diminta.

Akhirnya, ada peserta didik yang bisa me nyusun definisi dengan bahasanya sendiri. Pada pertemuan I, II, III, dan IV aktivitas peserta didik ada perubahannya walaupun tidak terlalu banyak, terlihat yang aktif masih peserta didik yang termasuk peringkat 10 besar pada kelas ini. Guru memotivasi peserta didik agar mau mempresen tasikan ke depan kelas apa yang telah didisku sikan dan membuat kesimpulan dari materi yang sudah dipelajari. Guru memberikan nasehat bah wa manusia adalah hamba Allah yang mempu nyai sifat pelupa, jadi selaku manusia kita sudah mempersiapkan diri seandainya lupa ada yang bisa kita lihat, yaitu catatan.

\section{b. Deskripsi Data Aktivitas Peserta Didik Siklus I}

Setelah dianalisis data observasi siklus I maka diperoleh hasil seperti pada Tabel 2 . Dengan melihat tabel tersebut dapat dikatakan bahwa ada aktivitas positif yang meningkat dan ada pula yang menurun dari pertemuan pertama sampai pertemuan keempat. Beberapa aktivitas, yaitu kehadiran peserta didik, peserta didik me ngumpulkan PR, peserta didik mencatat, dan pe serta didik yang memperhatikan penjelasan guru sudah mencapai optimal.

Tabel 2. Hasil Observasi Aktivitas Siklus I

\begin{tabular}{|c|c|c|c|c|c|}
\hline & \multicolumn{4}{|c|}{$\begin{array}{c}\text { Persentase Aktivitas } \\
\text { Pertemuan }\end{array}$} & \multirow{2}{*}{$\begin{array}{c}\text { Rata- } \\
\text { rata } \\
(\%)\end{array}$} \\
\hline & 1 & II & III & IV & \\
\hline 1 & 3.0 & 3.0 & 6.1 & 9.1 & 5.3 \\
\hline 2 & 0.0 & 3.0 & 3.0 & 6.1 & 3.0 \\
\hline 3 & 51.5 & 60.6 & 72.7 & 75.8 & 65.2 \\
\hline 4 & 90.9 & 93.9 & 97.0 & 90.9 & 93.2 \\
\hline 5 & 75.8 & 75.8 & 81.8 & 81.8 & 78.8 \\
\hline 6 & 87.9 & 81.8 & 84.8 & 84.8 & 84.8 \\
\hline 7 & 15.2 & 12.1 & 9.1 & 6.1 & 10.6 \\
\hline 8 & 87.9 & 87.9 & 90.9 & 87.9 & 88.6 \\
\hline 9 & 78.8 & 81.8 & 84.8 & 87.9 & 83.3 \\
\hline 10 & 9.1 & 15.2 & 18.2 & 18.2 & 15.2 \\
\hline 11 & 6.1 & 9.1 & 9.1 & 12.1 & 9.1 \\
\hline 12 & 9.1 & 6.1 & 6.1 & 3.0 & 6.1 \\
\hline
\end{tabular}

\section{c. Deskripsi Data Siklus I}

Dalam menggunakan pendekatan pembe rian reward dan pengaruhnya terhadap aktivitas belajar peserta didik dapat dikatakan bahwa ada mengalami peningkatan walaupun belum begitu menonjol. Aktivitas ini akan memberikan dam pak positif pada hasil belajar peserta didik. Pada siklus I dapat dilihat rata-rata dari hasil belajar dan ketuntasan secara klasikal. Hasil belajar sik lus I ini merupakan uji kompetensi I yang dilaku kan pada akhir siklus I. Pada siklus I ini soal yang diberikan berjumlah sepuluh butir soal.

Pada waktu pelaksanaan uji kompetensi I peserta didik sangat bersemangat dan antusias dalam melakukan ujian. Hal ini disebabkan pe serta didik telah terlatih mengerjakan soal-soal, dimana setiap akhir pertemuan peserta didik di berikan kuis dengan soal-soal yang ada. Hal ini juga didukung oleh masukan observer di setiap pertemuan mengenai aktivitas peserta didik yang dilakukan pada proses pembelajaran berlang sung. Guru melakukan tindakan perbaikan pada setiap pertemuan berikutnya karena peningkatan aktivitas dalam belajar akan memberikan dampak terhadap hasil belajar peserta didik secara klasikal.

Rekapitulasi pencapaian KKM pada uji kompetensi siklus I dapat dilihat pada Tabel 3. Berdasarkan tabel tersebut terlihat bahwa 13 pe serta didik (40\% dari 33 orang peserta didik) te 
lah tuntas pada aspek pemahaman konsep. Ini menunjukkan bahwa tingkat pemahaman konsep peserta didik pada siklus I sudah dikategorikan baik. Tetapi, hal ini belumlah memuaskan.

Tabel 3. Rekapitulasi Pencapaian KKM pada Uji Kompetensi Siklus I

\begin{tabular}{cccc}
\hline \multirow{2}{*}{ No } & \multirow{2}{*}{ Klasifikasi } & \multicolumn{2}{c}{ Ketuntasan } \\
& & Jumlah & \% \\
\hline 1. & Tuntas & 13 & 40 \\
2. & Belum Tuntas & 20 & 60 \\
\hline
\end{tabular}

\section{d. Refleksi Siklus I}

Setelah selesai serangkaian kegiatan pem belajaran pada siklus I, maka dilakukan kegiatan refleksi dengan tim observer. Walaupun kritikan dan saran selalu mereka berikan langsung setelah proses pembelajaran selesai pada setiap perte muan. Pada kegiatan refleksi, hasil observasi di ungkapkan bahwa pada akhir siklus untuk me ninjau penambahan hasil belajar peserta didik melalui aktivitas-aktivitas yang diberikan.

Hasil refleksi terhadap data pelaksanaan pa da siklus I terlebih dahulu diarahkan untuk mem bahas hal-hal yang berkaitan dengan aktivitas belajar peserta didik sehingga hasil belajar peser ta didik meningkat. Beberapa hal yang menjadi catatan dari pemberian reward pada siklus I dan solusi untuk pemberian reward pada siklus II.

\section{Hasil Penelitian pada Siklus II}

\section{a. Deskripsi Aktivitas Guru pada Siklus II}

Siklus II dilakukan pada pertemuan V, VI, VII, dan VIII dimana guru melakukan reward yang telah diberikan solusinya pada refleksi sik lus I. Setiap pertemuan guru menanyakan kesiap an peserta didik untuk menerima materi dan men cek kehadiran peserta didik pada hari itu. Sebe lum masuk ke materi baru guru selalu meninjau kembali materi yang sudah dipelajari dan me ngaitkannya dengan materi yang akan dipelajari. Guru mengingatkan materi kembali dan memoti vasi peserta didik agar mau untuk menjawab per tanyaan guru, memodelkan masalah, mengajukan pertanyaan, mengemukakan pendapat, dan mem presentasikan jawabannya ke depan kelas.

Pada kegiatan inti, guru meminta peserta di dik bekerja berpasangan dengan teman sebangku dalam mengerjakan LKS yang sudah tersedia. Gu ru meminta peserta didik menyelesaikan masalah kontekstual yang diberikan. Tindakan pada siklus II ini, guru lebih memberikan keyakinan kepada peserta didik untuk membaca, mencermati ma salah kontekstual yang ada, jika terdapat masalah yang sulit dalam menyelesaikannya guru menga takan jangan takut salah dalam menjawab perta nyaan karena nanti akan diperbaiki jika jawaban nya salah. Guru memberikan respon atas jawaban peserta didik dan bagi peserta didik yang meng alami kesulitan dalam menemukan konsep yang tepat, kegiatan guru pada siklus II adalah membe rikan pertanyaan dan mengarahkan peserta didik ke pokok masalah.

Guru membimbing peserta didik dengan melibatkan peserta didik dalam mengambil suatu kesimpulan. Pertanyaan peserta didik guru minta peserta didik lain untuk menjawabnya dan meng arahkan peserta didik agar mau mengemukakan pendapatnya. Guru memberikan umpan balik de ngan meminta peserta didik mengerjakan soal dan menuliskan jawabannya ke papan tulis. Akhirnya, pada siklus II ini sudah muncul wajahwajah baru dalam menjawab dan menuliskan ja waban yang diminta guru.

Peserta didik dapat menemukan konsep de ngan bimbingan dan arahan guru kemudian me minta peserta didik untuk menjelaskan kepada peserta didik lain atau teman sebangkunya. Bagi peserta didik yang mengalami kesulitan dalam memahami apa perintah di LKS mereka sudah mau bertanya langsung ke guru. Guru memberi kan arahan kepada peserta didik untuk membuat kesimpulan dari materi yang sudah dipelajari. Setelah peserta didik membuat kesimpulan baru guru menampilkan chart yang merupakan kesim pulan materi untuk menyamakan konsep yang didapatkan.

Pada akhir pertemuan tetap diberikan kuis untuk melihat hasil belajar peserta didik dan sete lah pertemuan ke VIII dilakukan uji kompetensi II untuk melihat pemahaman konsep dan peme cahan masalah peserta didik. Dalam hal ini dilihat perbandingan dengan hasil yang diperoleh dengan yang sebelumnya.

\section{b. Deskripsi Aktivitas Peserta Didik Siklus II}

Hasil pengamatan terhadap aktivitas peser ta didik selama siklus II dapat dilihat pada Tabel 4. Beberapa aktivitas, yaitu kehadiran peserta didik, peserta didik yang serius dalam belajar, peserta didik yang mengerjakan Latihan, peserta didik mengumpulkan PR, peserta didik mencatat, dan peserta didik yang memperhatikan penje lasan guru sudah mencapai optimal. Peserta didik yang bertanya, peserta didik menanggapi, dan pe serta didik yang mendapat reward lebih dari satu kali sudah dapat ditingkatkan. Peserta didik yang 
melamun dan peserta didik yang terlambat sudah dapat diturunkan aktivitasnya. Tentulah hal ini lebih baik lagi apabila dilakukan perbaikan tindakan yang dilakukan.

Tabel 4. Hasil Pengamatan Aktivitas Peserta Didik pada Siklus II

\begin{tabular}{cccccc}
\hline \multirow{2}{*}{$\begin{array}{c}\text { Akti } \\
\text { vitas }\end{array}$} & \multicolumn{4}{c}{$\begin{array}{c}\text { Persentase Aktivitas } \\
\text { Pertemuan }\end{array}$} & $\begin{array}{c}\text { Rata } \\
\text {-rata }\end{array}$ \\
\cline { 2 - 5 } & V & VI & VII & VIII & (\%) \\
\hline 1 & 15.2 & 18.2 & 18.2 & 21.2 & 18.2 \\
2 & 6.1 & 9.1 & 12.1 & 15.2 & 10.6 \\
3 & 75.8 & 78.8 & 84.8 & 87.9 & 81.8 \\
4 & 97.0 & 97.0 & 100 & 97.0 & 97.7 \\
5 & 84.8 & 90.9 & 97.0 & 97.0 & 92.4 \\
6 & 84.8 & 87.9 & 87.9 & 90.9 & 87.9 \\
7 & 6.1 & 3.0 & 3.0 & 3.0 & 3.8 \\
8 & 90.9 & 93.9 & 97.0 & 97.0 & 94.7 \\
9 & 90.9 & 90.9 & 93.9 & 93.9 & 92.4 \\
10 & 21.2 & 24.2 & 27.3 & 36.4 & 27.3 \\
11 & 15.2 & 18.2 & 21.2 & 24.2 & 19.7 \\
12 & 3.0 & 0.0 & 0.0 & 0.0 & 0.8 \\
\hline
\end{tabular}

\section{c. Deskripsi Data Hasil Belajar pada Siklus II}

Hasil belajar pada siklus II dilaksanakan dimana uji kompetensi II ini diikuti oleh 32 pe serta didik, 1 orang peserta didik dalam keadaan sakit. Adapun rekapitulasi pencapaian KKM pada uji kompetensi yang dilakukan siklus II dapat dilihat pada Tabel 5.

Tabel 5. Rekapitulasi Pencapaian KKM pada Uji Kompetensi Siklus II

\begin{tabular}{cccc}
\hline \multirow{2}{*}{ No } & Klasifikasi & \multicolumn{2}{c}{ Ketuntasan } \\
& Jumlah & Persentase \\
\hline 1. & Tuntas & 22 & 67 \\
2. & Belum & 11 & 33 \\
\hline
\end{tabular}

Pada Tabel 5 tampak bahwa peserta didik yang telah tuntas sudah mencapai lebih dari $65 \%$. Hasil dari uji kompetensi ini mengalami kema juan, karena peserta didik selain diberikan re ward dan punishment, mereka juga selalu dibe rikan latihan soal, kuis setiap habis pertemuan. Jadi, tentulah peserta didik terlatih untuk menger jakan soal-soal yang ada pada tes siklus II.

\section{e. Refleksi Siklus II}

Setelah selesai siklus II, dilakukan refleksi dengan tim observer untuk melihat aktivitas-ak tivitas positif yang sudah mencapai optimal dan yang dapat meningkat untuk mencapai optimal, aktivitas-aktivitas negatif yang sudah dapat diata si, serta hasil belajar peserta didik pada siklus II.
Pada dasarnya aktivitas peserta didik pada siklus II sudah mencapai tingkat keberhasilan yang ditetapkan.

\section{Pembahasan}

\section{Aktivitas Belajar Peserta Didik}

Selama proses pembelajaran kegiatan pe serta didik dapat ditingkatkan dimana peserta di dik dapat menjawab spontan setiap pertanyaan gu ru dan sudah mulai mengungkapkan alasan dari suatu persoalan. Hal ini disebabkan karena guru dan peserta didik berinteraksi dengan baik sehing ga terciptanya pembelajaran. Hal ini sesuai dengan yang dikemukakan oleh Nurhadi (2004) pengertian masyarakat belajar harus ada komuni kasi dua arah atau lebih.

Guru menggiring peserta didik ke pokok persoalan melalui penerapan bertanya, sehingga pembelajaran menjadi lebih hidup dan dengan sendirinya proses pembelajaran lebih baik. Se suai dengan yang dikemukakan oleh Rusman (2011) bahwa dengan pengembangan bertanya produktivitas pembelajaran akan lebih tinggi karena dengan bertanya guru dapat menggali be berapa informasi, membangkitkan respon peser ta didik, mengetahui seberapa besar rasa ingin tahu peserta didik, dan menyegarkan kembali pe ngetahuan peserta didik.

Aktivitas yang diamati pada penelitian ini merupakan aktivitas pembentukan diri peserta di dik, dimana peserta didik diharapkan bisa berbi cara di depan teman-temannya, bisa menjelaskan apa yang dikerjakan kepada temannya, ini meru pakan penanaman nilai karakter pada semua pe serta didik karena dengan berbagi ilmu atau peng alaman akan membiasakan untuk saling memberi dan menerima sifat positif dalam masyarakat bela jar, serta dapat mengambil kesimpulan dari mate ri yang sudah dipelajari.

Pembelajaran yang menggunakan pembe rian reward memberikan dampak positif terhadap aktivitas dan hasil belajar peserta didik. Melalui pemberian masalah kontekstual, peserta didik di beri kesempatan untuk menemukan konsep-kon sep matematika di bawah bimbingan guru. Seba gaimana pendapat Sanjaya (2004) bahwa ka rakteristik dalam pembelajaran kontekstual ada lah mengaktifkan kembali pengetahuan sebelum nya yang dimiliki peserta didik sehingga dipero leh pemahaman pengetahuan baru. Kemudian me nerapkan pengetahuan yang diperoleh dan dilan jutkan dengan refleksi. Penelitian lain juga mene mukan hasil yang sama. Nurmala (2014) melapor 
kan bahwa terdapat pengaruh positif yang signi fikan antara motivasi belajar terhadap aktivitas belajar siswa kelas X Akuntansi.

\section{b. Hasil Belajar}

Uji kompetensi matematika peserta didik terlihat secara keseluruhan mengalami pening katan. Peserta didik terlihat aktif dalam mencari dan mengkonstruksi pengetahuannya. Fakta ini selaras dengan hasil amatan yang telah dilakukan selama penelitian. Ini membuktikan bahwa peser ta didik melakukan proses pembelajaran dengan baik dan memiliki pemahaman yang baik terha dap materi pelajaran yang disajikan.

Hasil ini sejalan dengan temuan Widiyono (2019) yaitu terdapat pengaruh pemberian re ward dan punishment terhadap hasil belajar ma tematika peserta didik, yaitu sebesar $30.4 \%$. Sina ga (2019) juga menemukan bahwa terdapat hu bungan linear yang positif antara pemberian re ward dan punishment terhadap hasil belajar peser ta didik. Selanjutnya, hasil belajar Matematika sis wa yang menerapkan pendekatan scientific diiri ngi pemberian reward lebih baik dari pada hasil belajar matematika siswa tanpa menerapkan pen dekatan scientific diiringi pemberian reward pa da ranah kognitif, psikomotor, dan afektif di kelas XI SMKN 2 Padang Panjang. Metode ini dapat di gunakan untuk membuat peserta didik lebih aktif, kreatif, dan mandiri (Iltavia, 2019).

Prasetio dkk (2019) juga melaporkan bah wa dampak pemberian reward dan punishment dalam pembelajaran matematika mampu mening katkan antusias belajar matematika peserta didik pada tiga ranah yaitu ranah kognitif, ranah afektif dan ranah psikomotorik. Dampak positifnya yaitu memicu peserta didik untuk berkompetisi dan memotivasi belajar peserta didik.

\section{KESIMPULAN}

Simpulan dari penelitian adalah bahwa:

1. Aktivitas belajar peserta didik mengalami peningkatan yang menggembirakan melalui pembelajaran pemberian reward dan punish ment. Peningkatan aktivitas belajar tersebut terjadi pada semua aktivitas belajar yang me mang diharapkan meningkat.

2. Hasil belajar matematika melalui pemberian reward dan punishment juga mengalami pe ningkatan yang menggembirakan setelah di laksanakan pembelajaran selama dua siklus.

Berdasarkan kesimpulan hasil penelitian maka dapat diberikan saran agar:
1. Guru dapat menerapkan pembelajaran re ward dan punishment ini pada mata pelajaran matematika.

2. Hasil penelitian ini dapat dijadikan bahan ma sukkan bagi sekolah guna mengembangkan kemampuan profesional guru.

\section{DAFTAR PUSTAKA}

Abdurrahman, Mulyono. (2003). Pendidikan Ba gi Anak Berkesulitan Belajar. Jakarta: Rine ka Cipta.

Ahmad, Rohani. (2004). Pengelolaan Pengajar an. Jakarta: Rineka Cipta.

Arikunto, Suharsimi. (2010). Dasar-Dasar Eva luasi Pendidikan. Jakarta: Bumi Aksara.

Hamalik, Oemar. (2010). Proses Belajar Menga jar. Jakarta: PT Bumi Aksara

Ilmiyah dan Sumbawati. (2019). Pengaruh Media Kahoot dan Motivasi Belajar Terhadap Hasil Belajar Siswa. Journal Information Enginee ring and Educational Technology, 3 (1).

Iltavia, G S. (2019). Penerapan Pendekatan Scien tific Diiringi Pemberian Reward Dalam Pem belajaran Matematika. Inovasi Pendidikan, 6 (1), 39-45.

Juita dan Yusmaridi. (2019). Pengaruh Asesmen Portofolio Disertai Pemberian Costructive Feed back Terhadap Motivasi Belajar Maha siswa Biologi FTIK IAIN Kerinci. Jurnal Eksakta Pendidikan, 3 (1), 34-39.

Kunandar. (2008). Langkah Mudah Penelitian Tindakan Kelas Sebagai Profesi Guru. Jakar ta: Rajawali Pers.

Lestari, W. (2017). Pengaruh Kemampuan Awal Matematika dan Motivasi Belajar terhadap Hasil Belajar Matematika. Jurnal Analisa, 3 (1), 76-84.

Lu, Aitao. et. al. (2013). Effects of Reward and Punishment on Conflict Processing: Same or Different?. International Journal of Psycho logical Studies. 5 (1), 22-30.

Murni dkk. (2020). Efektivitas Penggunaan Bahan Ajar Kalkulus Berbasis ICT Terinteg rasi Masalah Kontekstual untuk Meningkat kan Aktivitas, Motivasi, dan Hasil Belajar Mahasiswa. Jurnal Eksakta Pendidikan, 4 (2), 171-178.

Ningrum, Arie. (2013). Pengaruh Pemberian Re ward dan Punishment Terhadap Motivasi Belajar Siswa MI Miftahul Ulum 02 Temba lang Tahun 2012/2013. Skripsi. Institut Aga ma Islam Negeri Walisongo Semarang. 
Nurmala dkk. (2014). Pengaruh Motivasi Belajar Dan Aktivitas Belajar terhadap Hasil Belajar Akuntansi. Jurnal Pendidikan, 4 (1), 1-10.

Ormrod, Jeanne Ellis. (2008). Psikologi Pendidik an: Membantu Siswa Tumbuh dan Berkem bang. Jakarta: Erlangga.

Prasetio, A., dkk. (2019). Analisis Dampak Pem berian Reward dan Punishment dalam Proses Pembelajaran Matematika. Jurnal Pedagogi dan Pembelajaran, 2 (3), 402-409.

Sanjaya, W. (2004). Strategi Pembelajaran Berorientasi Standar Proses Pendidikan. Ja karta: Kencana.

Sardiman A.M. (2009). Interaksi dan Motivasi Belajar Mengajar. Jakarta: PT Raja Grafindo Persada.

Shoimin, Aris. (2014). 68 Model Pembelejaran Ino vatif dalam Kurikulum 2013. Yogakarta: Ar-Ruzz Media.

Sinaga, CVR. (2019). Pengaruh Model Pem belajaran Trade A Problem Dengan Pembe rian Reward Terhadap Kemampuan Komuni kasi Matematis Siswa Kelas VII SMP N.1 Gunung Malela. MES (Journal of Mathe matics Education and Science), 4 (2), 209216.

Sudjana, Nana. (1989). Penilaian Hasil Belajar Mengajar. Bandung: PT Rosda Karya.

Sujiantari, NK. (2016). Pengaruh Reward dan Punishment terhadap Motivasi Belajar Siswa Dalam Pembelajaran IPS. Jurnal Jurusan Pendidikan Ekonomi, 7 (2), 1-10.

Tino, R.R. 2013. Pengaruh Reward dan Punish ment Terhadap Motivasi Belajar Siswa di Madrasah Aliyah Negeri Pangkalan Bun Ko tawaringin Barat Kalimantan Tengah. Skrip si. Universitas Islam Indonesia Yogyakarta.

Warsita, B. (2008). Teknologi Pembelajaran Landasan \& Aplikasinya. Jakarta: Rineka Cipta.

Widiyono dkk. (2019). Pengaruh Reward dan Pu nishment Terhadap Hasil Belajar Matemati ka Peserta Didik Kelas IV SDUT Bumi. Jur nal Pendidikan Dasar: Jurnal Tunas Nusantara Kartini Jepara, 1 (2), 102-109.

Woolfolk, Anita. (2009). Educational Psycholo gy Active Learning Edition. Yogyakarta: Pus taka Pelajar. 